\section{erythro, threo}

従来, 2 個の隣接する不斉炭素を有するジアステレオ マーの相対配置を表わすのに, Fisher 投影式でみて同 一の基が同じ側にあるものを erythro，異なるものを threo と規定されてきた。この命名法はそれぞれ ery throse, threose と同様な立体配置をもつことに由来す るため, それらに類似した采には適当であるが，他の系 に用いた場合主鎖の選択, 置換基の比較等に問題があり, 近年特に立体制御の分野で混乱をきたしている。

この混乱を解決するために, 野依らは一義的に erythro, threo を命名できる方法を提案した。即ち, C-C 結合 を切断して考え, $r e-s i$ または $s i-r e$ 面で結合したもの を erythro, re-re または $s i-s i$ 面で結合したものを threo と呼ぶことにした。本法により複雑な系も確実に命名す ることができる。

（中田 忠）
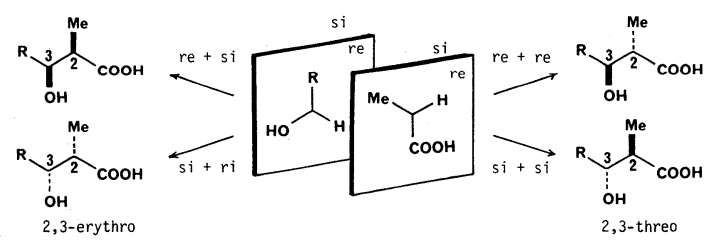

\section{結合表 (connection table)}

構造式をコンピュータで取り扱うための表現法の一つ。 まず構造式に含まれる原子または原子団をノード（節） とみなし番号を付ける。(通常は水素原子を省略して考 える。この番号付けを一義的に行ら方法もある。つい で,ノードとノードの間の結合の情報を与える。例えば, 結合の多重度に応じて $\mathrm{s}, \mathrm{d}, \mathrm{t}$ (あるいは $1,2,3$ )を付す。 アセトンを例にとると次のようになる。

\begin{tabular}{|c|c|c|c|}
\hline \multirow{2}{*}{ 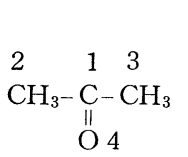 } & \multicolumn{3}{|c|}{ アセトンの結合表 } \\
\hline & $\begin{array}{l}\text { ノード } \\
\text { 番 号 }\end{array}$ & $\begin{array}{l}\text { 原子原子 } \\
\text { (付) }\end{array}$ & $\begin{array}{l}\text { 結合ノ一ドおよ } \\
\text { び多重度 }\end{array}$ \\
\hline & 1 & $\mathrm{C}$ & $2 \mathrm{~s} \quad 3 \mathrm{~s} \quad 4 \mathrm{~d}$ \\
\hline & 2 & $\mathrm{CH}_{3}$ & $1 \mathrm{~s}$ \\
\hline & 3 & $\mathrm{CH}_{3}$ & $1 \mathrm{~s}$ \\
\hline & 4 & $\mathrm{O}$ & $1 \mathrm{~d}$ \\
\hline
\end{tabular}

結合表には, 構造式のグラフとしての性質がすべて含 まれている。コンピュータ内では結合表に加えて, 図形 表示のための $\mathrm{x}, \mathrm{y}$ 座標がそれぞれのノードに付けられ ている。 （藤田眞作）

\section{syn, anti}

erythro, threo の従来の命名法の混乱をさけるため, 正宗らはその代りに syn, anti の用語を用いる新たな命 名法を提唱した。即ち, 主鎖を下図の如くジグザグ状に 書きあらわし，二つの置換基が共に紙面の同じ側 $(\alpha-\alpha$ または $\beta-\beta)$ にある場合を syn, 互いに逆側 $(\alpha-\beta$ また は $\beta-\alpha)$ にある場合をanti と呼ぶことにした。本法は<smiles>[R]C(O)[C@H](C)C(=O)O</smiles><smiles>[R]C(O)[C@H](C)C(=O)O</smiles><smiles>[R]C([X])C([R])O</smiles>

1,2-syn : $\beta-X$ 1,2-anti: $\alpha-x$ $\mathrm{X}=\mathrm{OH}, \mathrm{NH}_{2}$, etc.

4 級炭素のとき置換基の比較に難しさが生じることもあ るが, 殆んどの場合簡単に命名ができ, 相対配置との関 係も一見して容易に理解できることから多くの研究者に らけ入れられている。

現在, 相対配置を示す命名法として, syn/anti と先の erythro/threoの両者が主として使用されているが，こ の他にも pref/parf, $l / u$ 等を用いる命名法も提案されて おりその統一にはいたっていない。

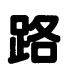

（中田 忠）

\section{Maxam-Gillbert 法}

DNA の塩基配列決定の一方法で化学分解法とも言い, 開発者の名前が付けられた。一般には $5^{\prime}$ ないし $3^{\prime}$ 末端 が標識された DNA 鎖を 4 分割し, それぞれの塩基に特 異性をもつ化学試薬（グアニン：硫酸ジメチル，グアニ ンとアデニン: ギ酸, チミンとシトシン：ヒドラジン, シトシン：塩共存ヒドラジン）で修飾（プリン, ピリミ ジン塩基の開環あるいは切断）反応を行う。このとき, 塩基の一部分が修飾を受けるような条件を選ぶ。次いで アルカリ（ピペリジン）で加熱すると, 修飾をうけた塩 基のところで DNA 鎖が切断する。 4 種の最終生成物を 別々にポリアクリルアミドゲル電気泳動にかけ鎖長の順 に分離し，このパターンをオートラジオグラムにとり， 標識した末端から順番に, どの塩基が存在するかを読み 取って配列を決める。分析する DNA 鎖は, 化学合成 DNA 鎖とか, 変性して一本鎖にした DNA の場合は, そのまま使えるが, 二本鎖 DNAの場合には, 両端が標 識されるので制限酵素で切断して分離する必要がある。 二本鎖 DNA の場合, M 13 ファージを用いる, ダイデ オキシ法がより簡便な方法である。

（千野恭義） 